\title{
Kajian Pengujian Bahan Aditif Semen Untuk Aplikasi Konservasi dan Pemugaran Candi
}

\author{
Dleh: \\ Puji Santosa, Sarman, Ajar Privanto \\ Balai Konservasi Peninggalan Borobudur
}

\section{A. Pendahuluan}

Salah satu fenomena yang terjadi pada upaya penanganan konservasi bangunan benda cagar budaya khususnya yang berada di lapangan, adalah satu bentuk pelapukan yang disebabkan oleh faktor penggaraman. Penggaraman merupakan salah satu jenis pelapukan yang banyak terjadi pada permukaan dan nat-nat batu candi. Populasi garam pada permukaan batu erat hubungannya dengan suhu udara, kelembaban udara, kandungan air pada batu, dan kandungan mineral pada batunya sendiri, serta garam-garam dari semen pada candi-candi yang pernah dipugar dengan menggunakan bahan semen sebagai spesi.

Akibat pengaruh suhu lingkungan dan penyinaraan matahari serta faktor-faktor lain, air yang terakumulasi di dalam batu akan menguap. Pada proses penguapan air melalui pori-pori atau celah-celah batu' yang membawa bahan-bahan mineral terlarut ke permukaan batu, pada waktu air menguap bahan-bahan mineral terlarut tersebut akan tertinggal di permukaan batu sehingga dalam jangka waktu tertentu terakumulasi menjadi endapan garam yang semakin tebal. Hal ini apabila tidak segera ditangani dengan serius akan berakibat batu menjadi rapuh. Oleh karena itu, maka perlu kiranya dilakukan tindakan preventif dan tindakan pembersihan pada permukaan batu yang telah ditumbuhi endapan garam tersebut. Salah satu tindakan preventif yang dilakukan untuk meminimalisir pertumbuhan endapan garam pada permukaan batu candi khususnya garam-garam yang berasal dari semen, adalah penggunaan bahan aditif semen, yaitu suatu bahan tambahan yang proses dan pengerjaannya dicampur dengan air sebagai air adukan semen dan pasir. Bahan aditif ini berfungsi sebagai bahan pengikat unsur kalsium yang ada pada semen, sehingga diharapkan setelah penggunaan bahan aditif in: proses pelapukan material oleh akibat adanya semen dapat di kurangi.

Berkaitan dengan permasalahan di atas, maka perlu kiranya dilakukan suatu kajian guna mengadakan pengujian tentang bahan aditif semen tersebut untuk diaplikasikan pada upaya konservasi dan pemugaran candi, baik yang terbuat dari batu maupun bata. Selanjutnya dengan melakukan observasi dan analisis berdasarkan percobaan-percobaan di laboratorium, kemudian dilakukan interpretasi detail untuk diketahui efektifitasnya, sehingga diharapkan penggunaan bahan aditif semen ini dapat meminimalisir dampak negatif yang mungkin akan terjadi dalam upaya konservasi dan pemugaran candi.

\section{B. Tujuan dan Manfaat Kajian \\ Tujuan kajian ini adalah} untuk mengetahui efektifitas penggunaan bahan aditif semen jenis Sikalatex. Kajian ini diharapkan dapat:

a. Memberikan informasi tentang bahan ad:tif semen jenis Sikalatex.

b. Memban:u mengetahui pengaruh penggunaan semen ditambah dengan bahan aditif jenis Sikalatex dalam upava konservasi dan pemugaran candi.

c. Dijadikan acuan penulisan karya ilmiah.

\section{Ruang Lingkup Kajian}

Ruang lingkup kajian ini dibatasi pada pengujian secara fisik dan kimiawi terhadap bahan aditif jenis Sikalatex yang telah dicampur dengan semen dalam beberapa variasi percobaan.

\section{Metode Kajian}

Kegiatan kajian ini diawali dengan survei untuk mencari dan menentukan berbagai merk semen yang umum digunakan di wilayah Pulau Jawa, yaitu Semen Tiga Roda, Semen Gresik, dan Semen Holcim. Kegiatan selanjutnya adalah pembuatan sampel pengujian di laboratorium. Dari ketiga merk semen tersebut dibuat beberapa seri pengujian dengan membuat benda uji berbentuk kubus ukuran $5 \times 5 \times 5$ $\mathrm{cm}$. Masing-masing dicampur dengan bahan aditif Sikalatex + air sebagai air adukan dengan perbandingan $1: 1$ s.d. $1: 4 \quad(1$ Sikalatex : 1 air s.d. 1 Sikalatex : 4 air) dan 1 buah PC murni (tanpa penambahan bahan aditif) sebagai kontrol pengujian. Selain itu juga akan dibuat benda uji campuran pasir semen dengan perbandingan 3:1 (3 pasir : 1 semen) dengan ukuran vang sama $5 \times 5 \times 5 \mathrm{~cm}$ dan mendapat perlakuan vang sama pula yaitu dicampur dengan bahan aditif Sikalatex dengan perbandingan 1:1 s.d 1:4, scrta 1 buah tanpa bahan aditif sebagai kontrol.

$$
\text { sampel-sampel rerschut }
$$

setelah keringkenudian dilakukin: 
- Pengukuran derajat keasaman $(\mathrm{pH})$, konsentrasi ion $\mathrm{OH}-$, conductivity, dan total dissolved solids (TDS), dengan cara sampel direndam dalam air hujan selama 10 siklus (1 siklus $=3$ hari perendaman). Pengukuran dilakukan menggunakan alat $\mathrm{pH}$ meter.

- Pengujian kadar kalsium terlarut dalam air rendaman, dilakukan secara titrimetri dan dilaksanakan selama 10 siklus.

Analisis fisik yang meliputi: densitas, berat jenis, porositas, kadar air jenuh, dan kuat tekan.

Pengujian daya serap air dan kapilaritas.

Pengukuran pori-pori sampel menggunakan Scanning Electron Microscope (SEM).

Seluruh data yang diperoleh dari hasil pengujian di laboratorium dan hasil studi banding yang dilaksanakan di Kompleks Candi Prambanan, dikompilasikan serta dikaitkan satu sama lain, kemudian dengan pendekatan dasar-dasar teori yang ada diharapkan dapat memberikan gambaran tentang bahan aditif semen jenis Sikalatex serta pengaruhnya terhadap benda cagar budaya.

\section{B. Data dan Pembahasan}

1. Pengujian Kimiawi Portland Cement (PC)

Parameter sampel yang dianalisis secara kimiawi meliputi kadar $\mathrm{SiO}_{2}, \mathrm{Fe}$, $\mathrm{SO}_{4}, \mathrm{Ca}, \mathrm{Mg}$, dan $\mathrm{Al}$. Metode yang digunakan dalam analisis ini adalah secara gravimetri (berdasarkan pengukuran berat) dan titrimetri (berdasarkan pengukuran volume suatu larutan standar dengan cara titrasi). Penentuan kadar $\mathrm{SiO}_{2}$ dilakukan dengan analisa gravimetri dimana berat yang didapat dari pelarutan s a mpel kemudian ditimbang. Sedangkan penentuan kadar mineralnya seperti $\mathrm{Fe}, \mathrm{SO}_{4}$, $\mathrm{Ca}, \mathrm{Mg}$, dan $\mathrm{Al}$ ditentukan dengan metode titrimetri. Metode ini berdasarkan pengukuran volume suatu larutan standar secara titrasi dengan menggunakan indikator. Larutan standard adalah larutan yang sudah diketahui konsentrasinya, dalam penelitian ini digunakan titriplex III (disodium salt of ethylenediamine tetra asetic acid) sebagai larutan standard dengan jenis titrasiny a d ala h komplexometri. Hasil analisis dari Semen Tiga Roda, Gresik, dan Holcim dapat dilihat pada tabel di bawah ini.

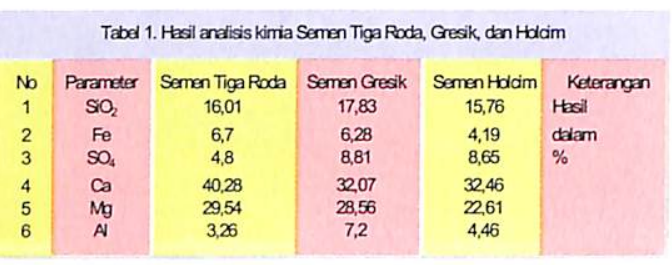

Dari tabel 1 di atas, nampak bahwa kadar kalsium Semen Tiga Roda lebih tinggi yaitu $40,28 \%$ bila dibanding dengan Semen Gresik (32,07\%) dan Semen Holcim $(32,46 \%)$, sedangkan kandungan unsur kimia yang dominan ketiga merk semen di atas adalah $\mathrm{Ca}, \mathrm{Mg}$, dan $\mathrm{SiO}_{2}$. Pengukuran derajat keasaman ( $\mathrm{pH})$ air rendaman dapat diukur langsung dengan $\mathrm{pH}$ meter menggunakan elektrode gelas kombinasi. $\mathrm{pH}$ meter dikalibrasi dengan larutan penyangga $\mathrm{pH} 7,00$ dan $\mathrm{pH}$
4,01. Sebelum pengukuran, elektrode dibilas dengan air bebas ion dan dikeringkan dengan tisu sebelum pengukuran setiap air rendaman. Hasil pengukuran air rendaman Semen Tiga Roda, Gresik, dan Holcim+Sikalatex pada $\mathrm{m}$ a s i n $\mathrm{g}-\mathrm{mas} \mathrm{ing}$ perbandingan serta PC murninya, selama 10 siklus perendaman adalah sebagai berikut:

- Semen Tiga Roda

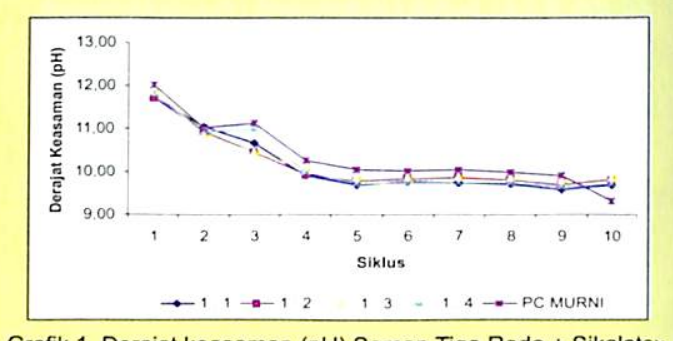

Grafik 1. Derajat keasaman $(\mathrm{pH})$ Semen Tiga Roda + Sikalatex

Dari grafik 1 di atas $\mathrm{nampak}$ bahwa semakin lama umur perendaman sampel, $\mathrm{pH}$ c enderung mengalami penurunan. Kondisi $\mathrm{pH}$ pada siklus ke-1 sampel $1: 1=$ $11,71,1: 2=11,69,1: 3=$ $11,85,1: 4=11,84$, dan PC murni=12,01. Sedangkan pada siklus ke-10 tercatat $1: 1=$ $9,68,1: 2=9,79,1: 3=$ $9,85,1: 4=9,70$, dan PC murni $=9,30$. Dari data tersebut, kondisi pH air rendaman sampel yang telah mendapat perlakuan pada siklus ke-10, berada di atas pH PC murni 
Semen Gresik

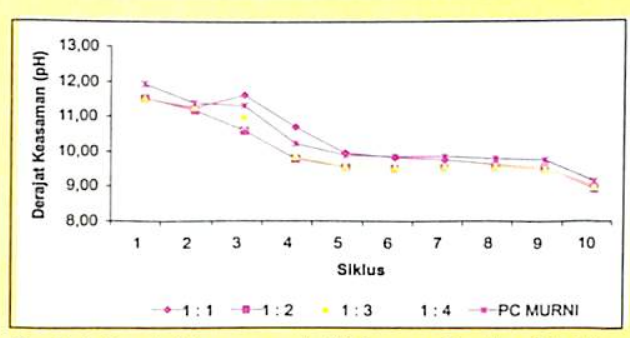

Grafik 2. Derajat keasaman (pH) Semen Gresik + Sikalatex

Pada grafik 2 di atas juga menunjukkan kondisi pH air rendaman mengalami penurunan. Hasil pengukuran $\mathrm{pH}$ pada siklus ke-1 sampel 1:1= $11,46,1: 2=11,46,1: 3=$ $11,45,1: 4=11,66$, dan PC murni=11,84. Sedangkan pada siklus ke-10 tercatat $1: 1=$ $8,94,1: 2=8,89,1: 3=$ $8,96,1: 4=8,90$, dan PC murni $=9,09$. Derigan melihat data tersebut, sampai dengan 10 siklus perendaman kondisi $\mathrm{pH}$ sampel yang mendapat perlakuan cenderung masih di bawah PC murni.

- Semen Holcim

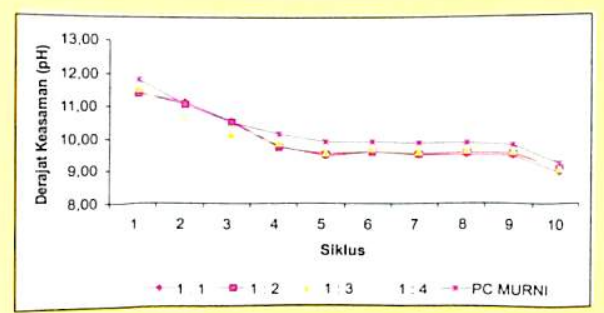

Grafik 3. Derajat keasaman $(\mathrm{pH})$ Semen Holcim + Sikalatex

Pada grafik 3, menunjukkan kondisi $\mathrm{pH}$ air rendaman sampel juga cenderung mengalami penurunan. Kondisi $\mathrm{pH}$ pada siklus ke-1 sampel $1: 1=$ $11,32,1: 2=11,31,1: 3=$ $11,44,1: 4=11,56$, dan
PC murni=11,73. Sedangkan pada siklus ke -10 tercatat $1: 1=$ $8,89,1: 2=9,00,1: 3=$ $8,99,1: 4=9,02$, dan PC murni=9,16. Sampai dengan 10 siklus perendaman, kondisi $\mathrm{pH}$ sampel yang telah mendapat perlakuan cenderung masih di bawah PC murni.

Dari data ketiga grafik derajat keasaman $(\mathrm{pH})$ di atas, sampai dengan 10 siklus perendaman menunjukkan kondisi $\mathrm{pH}$ pada Semen Gresik dan Semen Holcim+Sikalatex ternyata cenderung mengalami penurunan dibandingkan PC murninya, hal ini mengindikasikan bahwa Sikalatex mampu meredam naiknya $\mathrm{pH}$ air rendaman $\mathrm{PC}$ yang biasanya bersifat basa. Sedangkan pemakaian Sikalatex pada Semen Tiga Roda ternyata kurang efektif, hal ini ditunjukkan dengan masih tingginya $\mathrm{pH}$ air rendaman sampel yang mendapat perlakuan dibandingkan dengan PC murninya. Walaupun demikian, jika dilihat dari nilai kondisi $\mathrm{pH}$ yang didapatkan sampai dengan 10 siklus perendaman, masih ada kecenderungan untuk mengalami penurunan, sehingga tentunya hal ini masih perlu dilaksanakan monitoring lanjutan sampai dengan batas tertentu $(\mathrm{pH}$ stabil).

Hasil pengukuran konsentrasi ion $\mathrm{OH}$-Semen Tiga Roda, Gresik, dan Holcim + Sikalatex pada $\mathrm{mas} i \mathrm{ng}-\mathrm{mas} \mathrm{ing}$ perbandingan serta PC murninya dapat dilihat pada tabel 2 berikut:

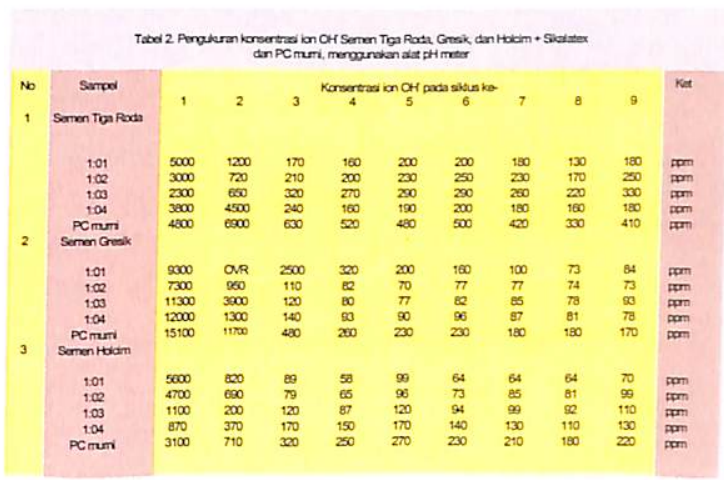

Dari tabel 2 di atas, terlihat bahwa konsentrasi ion $\mathrm{OH}$ air rendaman pada masingmasing sampel, sampai dengan 9 siklus pengujian rata-rata mengalami penurunan sekitar 85,1$99,4 \%$. Data menunjukkan bahwa penurunan paling signifikan terjadi pada Semen Gresik 1:4 yaitu dari 12000-78 ppm (99,4\%). Hal ini mengindikasikan bahwa bahan aditif Sikalatex mampu meredam naiknya ion $\mathrm{OH}^{-}$air rendaman, sehingga air rendaman PC yang biasanya bersifat basa berangsur-angsur dapat berkurang.

Sampai dengan 9 siklus pengujian, nilai konsentrasi ion $\mathrm{OH}$ - tertinggi tercatat pada Semen Tiga Roda, baik pada sampel yang mendapat perlakuan maupun PC murninya (lihat grafik 4).

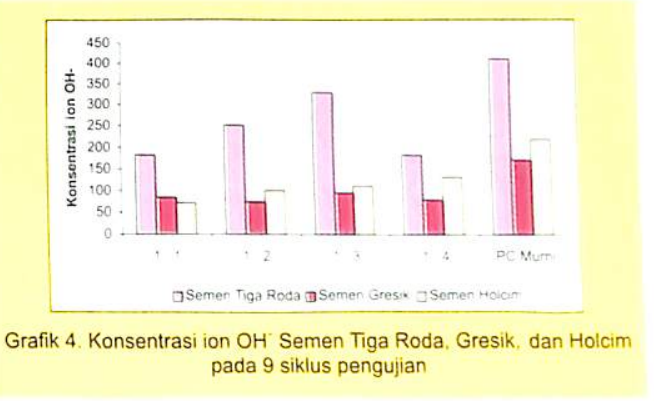

Conductivity atau nilai dara hantar listrik adalah ukuran 
kemampuan suatu bahan untuk menghantarkan arus listrik. Conductivity mencerminkan kadar garam yang terlarut. Peningkatan konsentrasi garam yang terlarut akan menaikkan nilai conductivity, yang diukur menggunakan elektrode platina. Data pengukuran conductivity air rendaman sampel Semen Tiga Roda, Gresik, dan Holcim+Sikalatex pada siklus ke-9 dapat dilihat pada tabel 3 berikut:

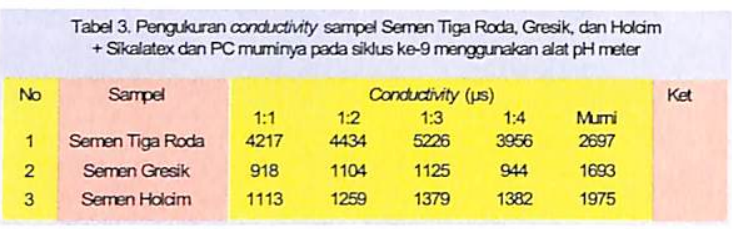

Pada tabel 3 menunjukkan data conductifity tertinggi tercatat pada Semen Tiga Roda yaitu dari 3956-5226 $\mu \mathrm{s}$, selanjutnya Semen Holcim 1113-1382 $\mu \mathrm{s}$. Sedangkan Semen Gresik menunjukkan conductifity terendah yaitu 918-1125 $\mu$ s. Pada Semen Gresik dan Holcim, nilai conductivity pada 9 siklus masih berada di bawah PC murni, hal ini menunjukkan bahwa bahan aditif Sikalatex mampu memperkecil tingkat pelarutan zat-zat terlarut dalam air rendaman Semen Gresik dan Holcim, s e d a ngkan nila i conductivity air rendaman Semen Tiga Roda berada di atas PC murni, hal ini mengindikasikan bahwa pemakaian bahan aditif Sikalatex kurang efektif pada Semen Tiga Roda.

Total Dissolve Solids (TDS) yaitu ukuran zat terlarut, baik zat organic maupun anorganic, misalnya garam dan lain-lain, yang terdapat pada sebuah larutan. Hasil pengukuran total dissolved solids (TDS) sampel Semen Tiga Roda, Gresik, dan Holcim ditambah bahan aditif Sikalatex pada siklus ke-9 dapat dilihat pada tabel 4 di bawah ini.

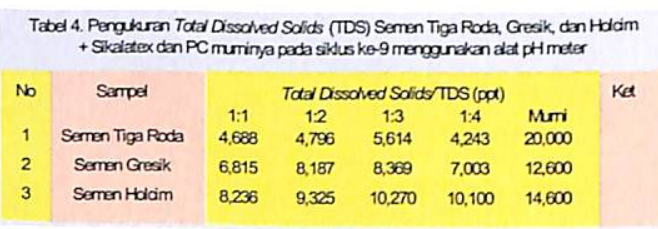

Dari tabel 4 tersebut, menunjukkan TDS tertinggi tercatat pada Holcim yaitu dari 8,23610,270 ppt, selanjutnya Semen Gresik 6,815-8,369 ppt. Sedangkan Semen Tiga Roda menunjukkan TDS terendah yaitu 4,243-5,614 ppt. Walaupun demikian nilai TDS masing-masing sampel pada 9 siklus masih berada dibawah PC murni. Hal ini mengindikasikan pemakaian bahan aditif Sikalatex ternyata mampu mengurangi daya pengikisan (pelarutan) semen.

Hasil pengukuran berbagai parameter tersebut di atas yang meliputi derajat keasaman $(\mathrm{pH})$, konsentrasi ion $\mathrm{OH}-$, conductivity, dan total dissolved solids (TDS), $\mathrm{p}$ e r b a $\mathrm{n}$ d i n g a $\mathrm{n}$ sampel+Sikalatex dengan PC murninya sampai dengan 9 siklus pengujian dapat digambarkan pada tabel 5 berikut :

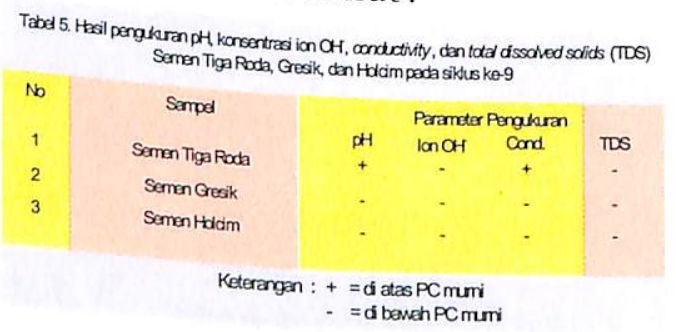

Pada tabel 5 di atas, hasil yang didapat menunjukkan Semen Tiga Roda + Sikalatex memiliki nilai lebih tinggi daripada PC murninya pada $\mathrm{pH}$ dan conductivity. Sedangkan pada Semen Gresik dan Holcim + Sikalatex rata-rata berada di bawah PC murninya.

Data pengamatan kadar kalsium terlarut air rendaman Semen Tiga Roda, Gresik, dan Holcim pada 10 siklus perendaman dapat dilihat pada tabel 6 berikut.

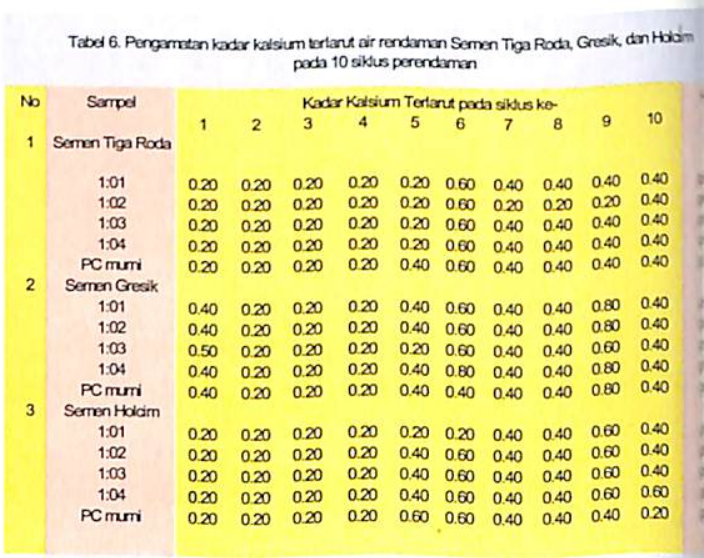

Dari tabel 6 di atas, sampai d engan 10 siklus perendaman menunjukkan nilai konstan kadar kalsium terlarut pada beberapa sampel. Walaupun demikian terdapat juga nilai peningkatan kadar kalsium terlarut pada sampel Semen Tiga Roda dan Holcim. Sedangkan pada Semen Gresik perbandingan 1:3 menunjukkan nilai penurunan kadar kalsium terlarut sebesar $0,10 \mathrm{ppm}$ yaitu dari $0,50 \mathrm{ppm}$ menjadi 0,40 ppm.

2. Pengujian Portland Cement $(\mathrm{PC})+$ Pasir Parameter pengujian secara kimiawi portland cement 
$(\mathrm{PC})+$ pasir dengan perbandingan 1:3 meliputi derajat keasaman $(\mathrm{pH})$, konsentrasi ion, conductivity, total dissolved solid, dan kadar kalsium terlarut. Metode yang digunakan dalam pengukuran derajat ke a s a man ( p H ), konsentrasi ion, conductivity, total dissolved solid adalah menggunakan alat $\mathrm{pH}$ meter, sementara pengukuran kadar kalsium terlarut menggunakan metode titrimetri yaitu berdasarkan pengukuran volume suatu larutan standart dengan cara titrasi. Hasil pengukuran derajat keasaman $(\mathrm{pH})$ Semen Tiga Roda, Gresik, dan Holcim + Pasir + Sikalatex dengan perbandingan 1:1 s.d. 1:4 pada 10 siklus perendaman, adalah sebagai berikut:

- Semen Tiga Roda + Pasir

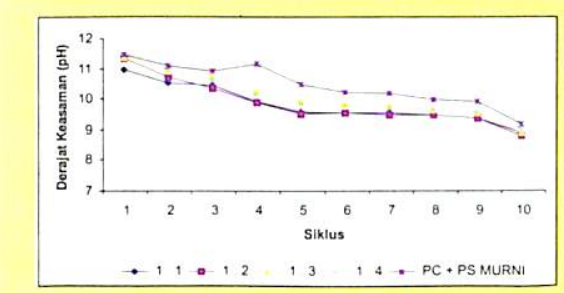

Grafik 5. Derajat keasaman (pH) Semen Tiga Roda + Pasir + Sikalatex dengan perbandingan 1:1 s.d. 1:4 dan PC+ PS murni

Pada grafik 5 terlihat $\mathrm{pH}$ air rendaman sampel cenderung mengalami penurunan. Kondisi $\mathrm{pH}$ pada siklus ke-1 sampel 1:1= $10,95,1: 2=11,31,1: 3=$ $11,37,1: 4=11,43$, dan $\mathrm{PC}+\mathrm{PS}$ murni $=11,46$. Sedangkan pada siklus ke-10 tercatat $1: 1=$ $8,88,1: 2=8,79,1: 3=$ $8,90, \quad 1: 4=9,01$, dan
PC+PS murni= 9,15.

Dari data tersebut, kondisi pH air rendaman sampel selama 10 siklus cenderung dibawah $\mathrm{pH}$ PC + PS murni.

- Semen Gresik + Pasir

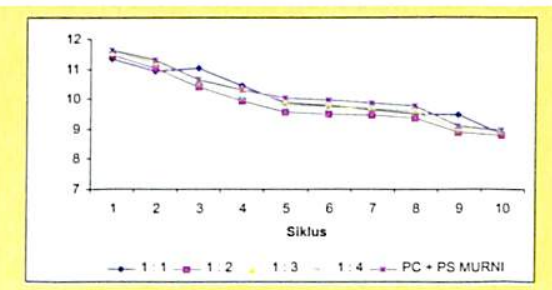

Grafik 6. Derajat keasaman ( $\mathrm{pH})$ Semen Gresik + Pasir + Sikalatex dengan perbandingan 1:1 s.d. 1:4 dan PC + PS murni

Pada grafik 6 terlihat $\mathrm{pH}$ air rendaman sampel juga cenderung menurun. Kondisi pH pada siklus ke-1 sampel $1: 1=11,36,1: 2=11,51$, $1: 3=11,58,1: 4=11,63$, dan PC+PS murni= 11,67. Sedangkan pada siklus ke-10 tercatat $1: 1=8,86,1: 2=8,84$, $1: 3=8,90,1: 4=8,95$, dan PC+PS murni= 9,00. Dari data tersebut, kondisi $\mathrm{pH}$ pada siklus ke-10 berada di bawah PC + PS murni.

- Semen Holcim + Pasir

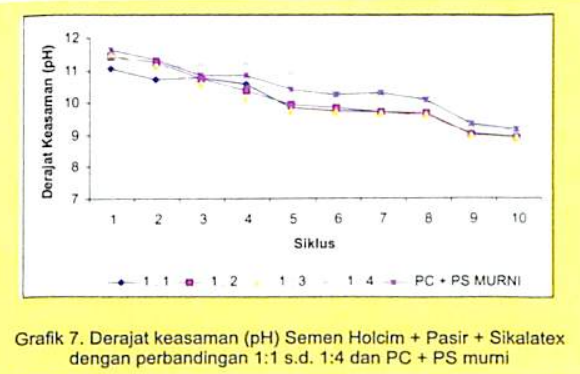

Pada grafik 7 terlihat pH air rendaman sampel cenderung mengalami penurunan. Kondisi pH pada siklus ke-1 sampel 1:1=11,06, $1: 2=11,44,1: 3=11,52$, $1: 4=11,46$, dan PC+PS murni= 11,63. Sedangkan pada siklus ke-10 tercatat $1: 1=$ $8,92,1: 2=8,90,1: 3=$ $8,90,1: 4=9,08$, dan PC+PS murni $=9,16$. Dari data tersebut, terlihat kondisi $\mathrm{pH}$ air rendaman sampel selama 10 siklus juga cenderung masih dibawah $\mathrm{pH} \mathrm{PC}+\mathrm{PS}$ murni.

Dengan melihat data ketiga grafik derajat keasaman $(\mathrm{pH})$ di atas, sampai dengan siklus ke-10, menunjukkan sampel yang ditambah bahan aditif Sikalatex ternyata cenderung mampu meredam naiknya pH air rendaman.

Sedangkan data $\mathrm{p}$ e $\mathrm{n} \mathrm{g} \mathrm{u} \mathrm{k} \mathrm{u} \mathrm{r} \mathrm{a} \mathrm{n}$ konsentrasi ion $\mathrm{OH}$ Semen Tiga Roda, Gresik, dan Holcim + Pasir + Sikalatex pada $\mathrm{m}$ a s ing - m a s ing perbandingan dapat dilihat pada tabel 7 berikut.

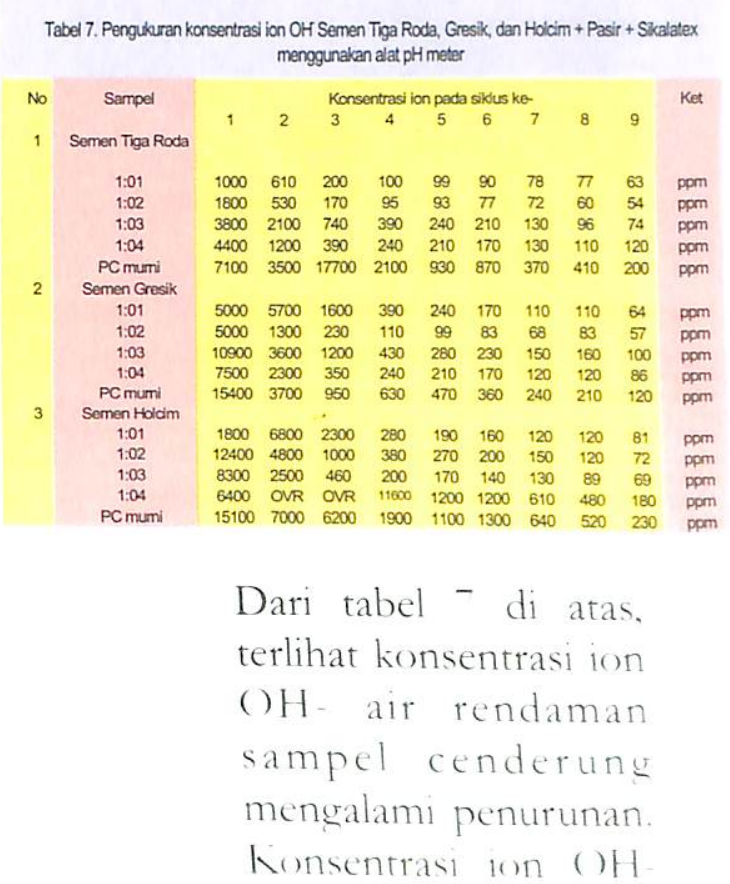


pada siklus ke-10 ratarata berada di bawah konsentrasi ion $\mathrm{OH}-$ PC + PS murni. Hal ini mengindikasikan bahwa pemakaian bahan aditif Sikalatex pada campuran pasir semen juga mampu meredam naiknya ion $\mathrm{OH}-$.

Hasil pengukuran conductivity sampel Semen Tiga Roda, Gresik, dan Holcim + Pasir + Sikalatex pada siklus ke-9, dapat dilihat pada tabel 8 di bawah ini.

\begin{tabular}{|c|c|c|c|c|c|c|c|}
\hline \multicolumn{8}{|c|}{$\begin{array}{l}\text { Tabel 8. Pengukuran conductivity Semen Tiga Roda, Gresik, dan Holcim } \\
+ \text { Pasir + Sikalatex pada siklus ke-9 menggunakan alat pH meter }\end{array}$} \\
\hline \multirow[t]{2}{*}{ No } & \multirow[t]{2}{*}{ Sampel } & \multicolumn{5}{|c|}{ Conductivity ( $\mu \mathrm{s})$} & \multirow[t]{5}{*}{ Ket } \\
\hline & & $1: 1$ & $1: 2$ & $1: 3$ & $1: 4$ & Murni & \\
\hline 1 & Semen Tiga Roda & 855 & 883 & 741 & 928 & 671 & \\
\hline 2 & Semen Gresik & 675 & 894 & 801 & 928 & 785 & \\
\hline 3 & Semen Holdim & 766 & 811 & 878 & 791 & 733 & \\
\hline
\end{tabular}

Dari tabel 8 di atas terlihat, nilai conductifity tertinggi tercatat pada Semen Tiga Roda yaitu dari 741-928 $\mu$ s, selanjutnya Semen Holcim 766-878 $\mu$ s. Sedangkan Semen Gresik menunjukkan conductifity terendah yaitu 675-928 $\mu \mathrm{s}$. Sampai dengan siklus ke-9, ternyata nilai conductivity pada masing-masing sampel berada di atas PC + PS murni.

Pengukuran total dissolved solids (TDS) sampel Semen Tiga Roda, Gresik, dan Holcim + Pasir + Sikalatex pada siklus ke-9, dapat dilihat pada tabel 9 di bawah ini.

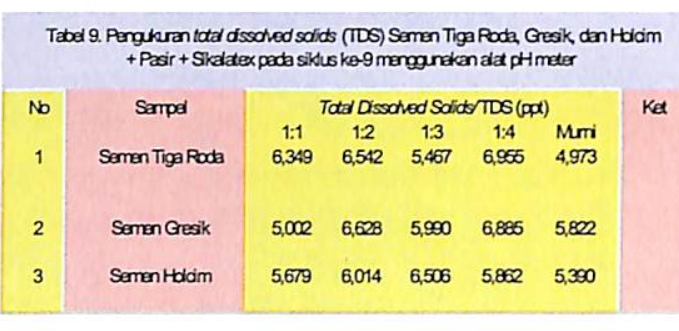

Tabel 9 menunjukkan TDS tertinggi tercatat pada Semen Tiga Roda yaitu dari 5,467-6,955 ppt, selanjutnya Semen Gresik 5,822-6,885 ppt. Sedangkan Semen Holcim menunjukkan TDS terendah yaitu 5,679-6,506 ppt. Nilai TDS masing-masing sampel pada siklus ke-9 ternyata berada di atas PC + PS murni. Selain itu, jika dibandingkan dengan awal siklus pengujian, nilai TDS yang didapat pada siklus ke-9 jauh lebih besar.

Hasil pengukuran derajat keasaman $(\mathrm{pH})$, konsentrasi ion $\mathrm{OH}_{-}$, conductivity, dan total dissolved solids, PC + Pasir + Sikalatex pada siklus ke-9 jika dibandingkan dengan $\mathrm{PC}+\mathrm{PS}$ murninya dapat digambarkan pada tabel 10 berikut:

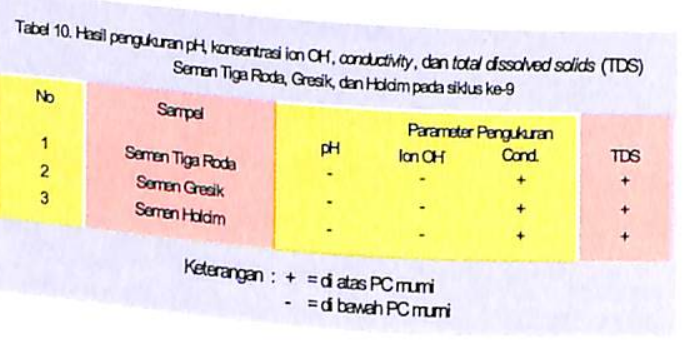

Hasil pengukuran yang ditunjukkan pada tabel 10 di atas, memberikan informasi bahwa pada ketiga produk semen pengujian tersebut memiliki nilai conductivity dan TDS yang lebih tinggi bila dibandingkan dengan $\mathrm{PC}+\mathrm{PS}$ murninya. Sedangkan pada pengukuran $\mathrm{pH}$ dan konsentrasi ion $\mathrm{OH}$ memiliki nilai dibawah PC+PS murni.

Data pengamatan kadar kalsium terlarut air rendaman Semen Tiga Roda, Gresik, dan Holcim + Pasir pada 10 siklus perendaman dapat dilihat pada tabel 11 berikut.

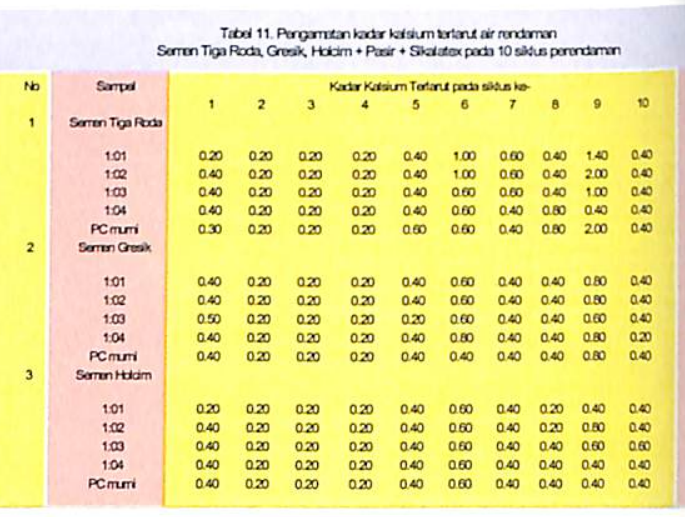

Dari tabel 11 di atas, sampai dengan siklus ke-10 menunjukkan nilai konstan kadar kalsium terlarut pada beberapa sampel. Walaupun demikian t e r d a pat jug a peningkatan kadar kalsium terlarut pada sampel Semen Tiga Roda dan Holcim. Khusus pada sampel Sem en Gresik perbandingan 1:3 dan 1:4 menunjukkan nilai penurunan kadar kalsium terlarut yaitu dari $0,50 \mathrm{ppm}$ menjadi $0,40 \mathrm{ppm}$ dan $0,40 \mathrm{ppm}$ menjadi $0,20 \mathrm{ppm}$. 
3. Analisis Fisik

Hasil analisis fisik dilakukan pada masing-masing sampel menunjukkan bahan aditif Sikalatex ternyata mampu meningkatkan kerapatan material, hal ini ditunjukkan dengan nilai densitas yang lebih besar dari PC murni. Selain itu, sampel telah ditambah bahan aditif Sikalatex pada beberapa perbandingan, nilai porositas dan kadar air jenuh cenderung menurun. Akibat adanya penurunan ini, daya serap air pada sampel juga akan menurun pula, sehingga dapat dikatakan bahwa bahan aditif Sikalatex ini dapat bersifat water proofing (kedap air).

Disamping itu, hasil foto scanning electron microscope (SEM) Semen Tiga Roda + Sikalatex perbanding a n 1:1 menunjukkan diamter pori berkisar antara 0,697-14,1 mikron, sedangkan Semen Tiga Roda murni diameter pori berkisar antara 0,97115,4 mikron. Sementara pada Semen Gresik + Sikalatex perbanding a n 1:1 menunjukkan diameter pori berkisar antara 0,389-8,67 mikron, sedangkan Semen Gresik murni diameter pori berkisar antara 0,386-11,9 mikron. Sedangkan hasil foto SEM Semen Holcim + Sikalatex perbandingan 1:1 menunjukkan diamter pori berkisar antara 0,584-7,84 mikron, sedangkan Semen Holcim murni diameter pori berkisar antara 0,545-11,1 mikron. Dari data foto SEM tersebut nampak bahwa Sikalatex dapat menambah kerapatan material, hal ini ditunjukkan oleh ukuran diameter pori-pori sampel yang mendapat perlakuan lebih kecil dibandingkan dengan sampel murni.

Data kuat tekan juga menunjukkan kenaikan pada sampel yang mendapat perlakuan daripada PC murni, sehingga dari nilai kuat tekan tersebut ternyata bahan aditif Sikalatex mampu menambah kekuatan (daya dukung) portland cement.

Sedangkan hasil analisis fisik Semen Tiga Roda, Semen Gresik, dan Semen Holcim + pasir (1:3) yang ditambah bahan aditif Sikalatex, secara umum menunjukkan nilai densitas masing-masing sampel lebih besar dari PC murni. Sehingga dapat dikatakan Sikalatex mampu menambah kerapatan material. Selain itu, sampel yang mendapatkan perlakuan dengan ditambah bahan aditif Sikalatex pada beberapa perbandingan, nilai porositas dan kadar air jenuh cenderung menurun. Akibat adanya penurunan ini, tentunya daya serap air pada sampel juga akan menurun pula, sehingga dapat dikatakan bahwa bahan aditif Sikalatex ini dapat bersifat water proofing (kedap air). Disamping itu dari hasil foto scanning electron microscope (SEM) Semen Tiga Roda + pasir + Sikalatex perbanding a n 1:1 menunjukkan diamter pori berkisar antara 0,800-3,71 mikron, sedangkan Semen Tiga Roda + pasir murni diameter pori berkisar antara 1,56-31,5 mikron. Pada Semen Gresik + Pasir + Sikalatex perbandingan 1:1 menunjukkan diamter pori berkisar antara 0,975-6,55 mikron, Semen Gresik+pasir murni diameter pori berkisar antara 1,04-7,40 mikron. Sedangkan hasil foto SEM Semen Holcim + pasir + Sikalatex perbandingan 1:1 menunjukkan diamter pori berkisar antara 0,975-4,02 mikron, sementara Semen Holcim + pasir murni diameter pori berkisar antara 0,554-15,8 mikron. Dari data hasil foto SEM tersebut nampak pula bahwa Sikalatex dapat menambah kerapatan material, hal ini ditunjukkan oleh ukuran diameter poripori sampel yang mendapat perlakuan lebih kecil dibanding dengan sampel murni.

Data kuat tekan juga menunjukkan kenaikan pada sampel yang mendapat perlakuan daripada PC murni, sehingga dari nilai kuat tekan tersebut ternyata bahan aditif Sikalatex mampu menambah kekuatan (daya dukung) portland cement + pasir.

4. Pengujian Daya Serap Air

Sampel yang digunakan dalam penguiian daya serap air ini adalah batu andesit ukuran $5 \times 5 \times 5 \mathrm{~cm}$ yang telah diolesi PC+Sikalatex dan PC + Pasir + Sikalatex dengan beberapa perbandingan. Pengujian dilaksanakan dengan cara merendam sampel pada interval waktu 1 jam, 3 jam, 6 jam, dan 24 jam. Hal ini dilaksanakan guna mengetahui dara serap sampel terhadap air, sehingga dari hal tersebut akan diketahui apakah Sikalatex dapat bersifat water proofing. Hasil penguiian 
menunjukkan masing-masing sampel yang mendapatkan perlakuan ditambah bahan aditif Sikalatex, mempunyai daya serap air yang lebih kecil daripada PC murni. Pada Semen Tiga Roda 2,63-4,09\% PC murni 6,69\%, Semen Gresik 2,53-4,17\% PC murni 6,37\%, dan Semen Holcim 3,38-6,92\% PC murni 7,89\%. Sedangkan pada Semen + Pasir + Sikalatex juga mempunyai nilai daya serap air yang lebih kecil daripada PC murni yaitu pada Semen Tiga Roda 3,69-4,10\% PC murni 5,60\%, Semen Gresik 3,51-4,47\% PC murni 7,85\%, dan Semen Holcim 3,52$4,80 \%$ PC murni $6,51 \%$. Sehingga dari data tersebut mengindikasikan bahwa Sikalatex memang bersifat water proofing.

5. Pengujian Kapilaritas

Pengujian kapilaritas dilakukan dengan cara sebagai berikut: sampel dikeringkan dalam oven pada suhu $400 \mathrm{C}$, kemudian beratnya ditimbang. Selanjutnya sampel diletakkan di atas batu porus yang direndam dengan air (di bawah sampel yang diuji diberi kertas saring), kemudian setiap 1 jam selama 8 jam sampel tersebut ditimbang. Sebelum ditimbang permukaan sampel vang kontak dengan air dikeringkan dengan kain lap, kemudian koefisien kapiler dihitung dengan rumus:

$$
C=\frac{100 P}{S \sqrt{t}}
$$

Dengan

C: koefisien kapilaritas,

$\mathrm{P}$ : perbedaan berat dalam waktu penyerapan $\mathrm{t}$ menit (gram),

S: luas permukaan batu yang diuji $(\mathrm{cm} 2)$,

t : waktu (menit)

Hyvert, 1970, 106)

Hasil pengujian PC + Sikalatex pada masing-masing sampel menunjukkan penurunan angka koefisien kapilaritas dibandingkan PC murni, yaitu pada Semen Tiga Roda berkisar 60,4-74,3\%, Semen Gresik 40,2-80\%, dan Semen Holcim 56,1-78,7\%. Begitu juga hasil pengujian pada PC + Pasir + Sikalatex juga menunjukkan penurunan angka koefisien kapilaritas dibandingkan PC+PS murni, yaitu pada Semen Tiga Roda berkisar $75,6-90,2 \%$, Semen Gresik $77,3-85,3 \%$, dan Semen Holcim 67,4-90,4\%. Sehingga dari kedua data tersebut mengindikasikan juga bahwa ternyata Sikalatex memang dapat bersifat sebagai water proofing (kedap air).

6. Studi Banding

Studi banding dilaksanakan di kompleks Candi Prambanan Propinsi Daerah Istimewa Yogyakarta, khususnya pada Candi Garuda. Candi Garuda merupakan awal dari kegiatan rehabilitasi kompleks Candi Prambanan pasca gempa 27 Mei 2006. Pada kegiatan rehabilitasi tersebut salah satunya telah memakai bahan aditif semen jenis Sikalatex yang dicampur dengan air sebagai air adukan semen. Hal ini dilaksanakan karena dalam rehabilitasi Candi Garuda semen masih digunakan untuk mengisi celah-celah batu. Perbandingan air adukan semen yang ditambah Sikalatex adalah 3:1 (3 bagian air : 1 bagian Sikalatex). Selain itu untuk memperkuat penyambungan batu yang semula kuningan diganti dengan angkur besi ulir agar lebih kuat.

Penggunaan Sikalatex pada upaya rehabilitasi Candi Garuda, adalah sebagai penutup nat-nat pada bagian atap dan untuk menginjeksi pada bagian-bagian yang terjadi retakan. Selain itu juga digunakan sebagai perkuatan penyambungan terhadap angkur. Bagian-bagian Candi Garuda yang telah menggunakan Sikalatex sebagai bahan campuran semen adalah pada bagian atap serta pada bagian-bagian batu yang berdiri sendiri seperti ratna.

Data studi banding hasil pengujian bahan aditif Sikalatex yang telah dilaksanakan pada kegiatan rehabilitasi kompleks Candi Prambanan sebagai berikut:

a. Derajat keasaman $(\mathrm{pH})$ air rendaman sampel yang diuji nampak bahwa semakin lama umur pengeringan sampel, $\mathrm{pH}$ cenderung turun, sedangkan PC yang dicampur air tanpa Sikalatex pH nya mencapai 10 lebih, sementara PC yang dicampur air dengan Sikalatex pH nya cenderung turun mencapaio.

b. Kadar kalsium terlarut dari air rendaman dari masing masing sampel pengujian adalah sebagai 
berikut:

\begin{tabular}{|c|c|c|c|}
\hline No & Sampel & $\mathrm{pH}$ & Kadar Kalsium \% \\
\hline 1 & $\mathrm{PC}+$ air Sikalatek & 7 & 2 \\
\hline 2 & PC + air & 8 & 2,8 \\
\hline 3 & PC + pasir + air & 8 & 2,67 \\
\hline 4 & Sikalatek & & \\
\hline & PC + pasir + air & 8 & 2,2 \\
\hline
\end{tabular}

Ta bel d i a tas menunjukkan bahwa kadar kalsium terendah adalah PC + air Sikalatex yaitu $2 \%$, dan bila dibandingkan dengan PC + air kadar kalsiumnya berselisih $0,8 \%$.

c. Data kuat tekan dari sampel pengujian yang berumur 7 hari adalah sebagai berikut:

\begin{tabular}{|c|c|c|}
\hline No & Sampel & Kuat Tekan $(\mathrm{Kg} / \mathrm{cm} 2)$ \\
1 & PC + Air Sikalatex & 152 \\
2 & PC + Air & 80 \\
3 & PC + Pasir + Air & 40 \\
& Sikalatex & \\
\hline 4 & PC + Pasir + Air & 88 \\
\hline
\end{tabular}

$\mathrm{T}$ a b e l d i a t a s menunjukkan bahwa PC dengan campuran air+Sikalatex ternyata menambah kekuatan (daya dukung) dari PC sebesar $53 \%$ yaitu dari 80 $\mathrm{kg} / \mathrm{cm}^{2}$ menjadi 152 $\mathrm{kg} / \mathrm{cm}^{2}$.

Dari ketiga data yang didapatkan pada studi banding di kompleks Candi Prambanan tersebut, nampaklah adanya keselarasan data dari pengujian yang tim laksanakan, baik pada nilai derajat keasaman $(\mathrm{pH})$, kadar kalsium terlarut, maupun kuat tekan.

\section{Kesimpulan dan Saran}

1. Kesimpulan

a. Sifat-sifat fisik bahan aditif Sikalatex pada aplikasi portland cement (PC):

Sikalatex efektif meredam naiknya $\mathrm{pH}$ air rendaman $\mathrm{PC}$ yang biasanya bersifat basa, hal ini terlihat dari semakin menurunnya $\mathrm{pH}$ dan konsentrasi ion $\mathrm{OH}$ pada 10 siklus perendaman.

- Sikalatex efektif $\mathrm{men} g \mathrm{ur}$ a $\mathrm{g}$ i pelarutan kalsium bebas, terlihat sampai dengan siklus ke-10 menunjukkan nilai konstan kadar kalsium terlarut pada sampel Semen Gresik. Walaupun demikian terdapat juga peningkatan kadar kalsium terlarut pada sampel Semen Tiga Roda dan Holcim rata-rata sebesar 0,20 ppm. Namun demikian, secara um um Sikalatex dapat menekan kadar kalsium terlarut meskipun tidak 100 $\%$.

Sikalatex dapat digunakan sebagai bahan tambahan (aditif) untuk meningkatkan daya dukung PC, hal ini terlihat dari penambahan nilai kuat tekan sekitar $57 \%$ dibanding PC murni. Sikalatex juga mampu menambah ketahanan terhadap kikisan material yang ditunjukkan dengan kecilnya nilai total dissolved solids (TDS) air rendaman sampel + Sikalatex dibanding PC murni

Sikalatex bersifat water proofing (kedap air), hal ini terlihat dari penurunan nilai daya serap air sekitar $16,95 \%$ dan kadar air jenuh sekitar $22,67 \%$. Selain itu juga ditunjukkan oleh nilai koefisien kapilaritas yang semakin menurun bila dibanding dengan PC murni yaitu sekitar 32,7\%.

Sikalatex mampu $\mathrm{m}$ e $\mathrm{n} \mathrm{a} \mathrm{m}$ b a $\mathrm{h}$ kerapatan material, hal ini terlihat dari peningkatan nilai densitas sampel + Sikalatex sebesar $88.67 \%$, disamping itu hasil analisis SEM juga menunjukkan penurunan diamater pori-pori sampel + Sikalatex daripada PC murni yaitu berkisar antara 0,389-14,1 mikron, sedangkan PC murni berkisar antara 0,386-15,4 mikron.

Sikalatex efektif diaplikasikan pada Semen Gresik, terlihat dari beberapa pengamatan seperti $\mathrm{pH}$, konsentrasi ion $\mathrm{OH}-$, conductivity , dan total dissolved solids, menunjukkan Semen Gresik berada pada level bawah bila dibandingkan 
dengan Semen Tiga

Roda dan Holcim.

Selain itu, hasil

pengujian kadar

kalsium terlarut

Semen Gresik + Air

Sikalatex $1: 3$ pada 10

siklus perendaman, m e n u $\mathrm{n} \mathrm{ukkan}$ adanya penurunan yaitu dari $0,50 \mathrm{ppm}$ menjadi 0,40 ppm.

Sikalatex kurang efektif diaplikasikan pada Semen Tiga Roda, terlihat dari kenaikan nilai conductivity air rendaman pada akhir siklus berada di atas PC murni, yaitu 3956-5226 $\mu \mathrm{s}$ pada S e m e n $T$ i g a Roda+Sikalatex sedang PC murni $2697 \mu \mathrm{s}$, sehingga dapat diasumsikan bahwa terjadi pen ing k a t a n pelarutan zat-zat terlarut dalam air rendaman. Selain itu j u g a b i l a $\mathrm{dib}$ a n dingkan dengan Semen Gresik dan Holcim, maka Semen Tiga Roda mempunyai nilai pH dan konsentrasi ion $\mathrm{OH}$ yang lebih tinggi. Sementara dari data $10 \quad \mathrm{~s}$ i k l u s perendaman tercatat adanya kenaikan $\mathrm{kadar} \mathrm{kalsium}$ terlarut sebesar 0,20 ppm.

Sikalatex kurang efektif iuga diaplikasikan pada Semen Holcim, hal ini terlihat dari nilai TDS Semen Holcim yang lebih tinggi dari Semen Tiga Roda dan Gresik sekitar $61 \%$, yaitu antara 8,236-10,270 ppt, sedangkan pada Semen Tiga Roda antara 4,243-5,614 ppt dan Semen Gresik antara 6,8158,369 ppt. Selain itu juga dilihat dari kenaikan kadar kalsium terlarut Semen Holcim dalam 10 siklus perendaman yang mencapai $0,20 \mathrm{ppm}$, dimana hal ini sama dengan Semen Tiga Roda.

b. Dalam pemugaran benda cagar budaya dari bahan batu yang terpaksa menggunakan semen sebagai spesi, penggunaan Sikalatex sangat diperlukan untuk mencegah dampak negatif yang ditimbulkan dari penggunaan semen tersebut (pelarutan 2. Saran kalsium).

a. Perlu dilasanakan pengamatan lanjutan untuk melihat dampak yang terjadi, baik positif maupun negatif dari akibat penggunaan bahan Sikalatex.

b. Perlu dilaksanakan kajian lebih lanjut terhadap bahan aditif jenis Sikalatex ini sebagai bahan perekat pada upaya $P$ e $n$ a $n g$ a $n$ a $n$ penyambungan batu.

c. Perlu dilaksanakan kajian lebih lanjut terhadap bahan aditif jenis Sikalatex ini sebagai bahan pemugaran seperti pada pembuatan beton cor dan kolom.

d. Perlu dilaksanakan kajian lebih lanjut penggunaan bahan aditif jenis Sikalatex terhadap semensemen produksi luar Pulau Jawa.

e. Perlu dilaksanakan kajian lebih lanjut untuk bahan aditif jenis Sikalatex ini terhadap ketahanan pada

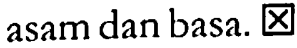

\section{Daftar Pustaka}

Anonim, 1972, Peraturan Semen Portland Indonesia NI-8, Yayasan Dana Normalisasi Indonesia, Departemen Pekerjaan Umum dan Tenaga Listrik, Direktorat Jenderal Cipta Karya, Lembaga Pendidikan Masalah Bangunan.

Anonim, 2005, Technical Data Sheet Sikalatex (Bonding Agent), Edition 2, Bogor.

A no n im, 2009 , http://id.wikipedia.org/wiki /Kalsium_hidroksida.

Anshory Irvan, 1987, Penuntun Pelajaran Kimia, Ganeca Exact, Bandung.

Aris Munandar,1999, Studi Pelapukan Batu Candi Siwa Prambanan, Balai Studi dan Konservasi Borobudur, Magelang.

Day Ir R.A and Underwood A.L, 1986, Analisis Kimia Kwantitatif, Erlangga, Jakarta.

De Beaufort C.C.T., P.H. Debel, C. Voute, G. Hyvert, 1970, The Restoration of Borobudur, UNESCO.

Torraca. G, 1977, Building Materials and Deterioration Procces, International Centre for Conservation. 